\title{
Substance Abuse and Aggressive Behavior among Adolescents
}

\author{
Fauziah, I. ${ }^{1}$, Mohamad, M. S. ${ }^{1}$, Chong, S. T. ${ }^{1} \&$ Azmi Abd Manaf ${ }^{1}$ \\ ${ }^{1}$ School of Psychology and Human Development, Faculty of Social Sciences and Humanities, Universiti \\ Kebangsaan Malaysia, Bangi, Malaysia \\ Correspondence: Fauziah, I., School of Psychology and Human Development, Faculty of Social Sciences and \\ Humanities, Universiti Kebangsaan Malaysia, 43600 UKM Bangi, Selangor, Malaysia. Tel: 60-3-8921-3652. \\ E-mail: ifauziah@ukm.my
}

Received: June 4, $2012 \quad$ Accepted: June 16, $2012 \quad$ Published: July 16, 2012

doi:10.5539/ass.v8n9p92 URL: http://dx.doi.org/10.5539/ass.v8n9p92

\begin{abstract}
Social workers, psychologists and psychopharmacologists have devoted little attention to study the direct relationship between drugs and adolescents' aggression. The main objective of this study was therefore to determine the extent of the level of aggressive behavior among adolescents who underwent rehabilitation of drug abuse. This study also sought to find out the relationship between type of drugs used with aggressive behavior among adolescents. Respondents were 200 adolescents from three juvenile Henry Gurney schools in Malaysia who took part in this exploratory cross-sectional survey research design. A set of questionnaire was constructed by the researcher based on the Aggression Questionnaires (AQ) scale. Results showed that the majority of adolescents ( 95 percent) indicated an aggressive behavior of moderate to high level. The result of the study also found that adolescents who have been using heroin $(r=0.016, p<0.05)$ and morphine drugs $(r=0.181, p<0.05)$ showed significant correlation with aggressive behavior. The findings provided evidence for the significant role of the goverment to enhance rehabilitation modules for adolescents involved in drug abuse. Education on how to effectively deal with aggressive behavior among adolescents at risk should be emphasized for building positive behavior among adolescents in order to produce potential young generation in the future.
\end{abstract}

Keywords: substance abuse, aggressive behavior, types of drug use, adolescents

\section{Introduction}

The young generation is the future leaders that are expected to determine the direction of the country to achieve excellence. Therefore, an investment in human capital of young generation is crucial to prepare this group in order to withstand the current challenges of globalization. According to Abd. Rahim et al. (2006), adolescence is the critical stage of mental and physical development. The literature of adolescence frequently portrays it as a negative stage of life - a period of storm and stress to be survived or endured (Arnett, 1999). When many adolescents today have much free unsupervised time compared with previous generations (Sickmund et al., 1997), there is tendency that they may be involved with unhealthy activities such as drug abuse if they are not monitored by parents.

In Malaysia, drug was named as the nation's number one enemy in 1893 and ever since then, the fight against drugs was conducted aggressively by widening the awareness scope at all age level (Fauziah et al., 2011a). Based on the National Drug Agency of Malaysia, statistics showed that young people were the group most exposed to drug addiction. This can be supported by statistics showing that the number of drug addicts detected from January-June 2011 consisted of 4,925 young people (Drug Report, 2011). The records showed that the most popular drug used was heroin, as recorded by 2,207 people. This was followed by morphine users with 2,018 and methamphetamine users with 1,040. In addition, 1,077 people have been detected using amphetamine-type-stimulants (ATS), which consisted of the synthetic drug methamphetamine, ecstasy and amphetamine pills.

According to Taylor and Husizer (1998), a wide variety of drugs are presumed to be related to aggressive behaviors. Many researchers also state that a range of drugs, particularly cocaine and amphetamines (including 
methamphetamine) are associated with increased violent and aggressive behaviors (Boles \& Miotto, 2003; Davis, 1996; Moore \& Stuart, 2003; Chermack \& Blow, 2002; MacDonald et al., 2008). Meanwhile, the effect of some drugs including cocaine, amphetamines and benzodiazepines have been found to increase violence and aggressive behaviors (Kuhns, 2005; Moore \& Stuart, 2003; Ben-Porath \& Taylor, 2002) and can also influence them negatively when they are seeking employment opportunities (Fauziah et al., 2011b)

According to Baron and Richardson (1994), aggression is any form of behavior directed toward the goal of harming or injuring another living being who is motivated to avoid such treatment. Although the term aggression refers to a wide spectrum of behaviors in the psychological literature, it is defined as any behavior intended to harm another individual who is motivated to avoid being harmed (Coie \& Dodge, 2000; Geen, 1990, 1998a, 1998b). Berman et al. (1993) suggested that aggression can result from psychopharmacological effects of morphine use.

Some research findings portray that human aggressive behavior may arise from the use of a wide range of dangerous drugs. This statement can be supported by the study about intimate partner violence in China which found that partners who used illicit drugs were more likely to abuse their spouses physically, sexually, or both (Xu et al., 2005). Another study conducted by Reid et al. (2007) in Atlanta, USA, found that higher levels of ecstasy users exhibited higher rates of aggressive and violent behavior. The findings of the study showed that drug use can have consequences on aggressive behaviors among drug users. In the study of violence in youth holiday resorts among young German, Spanish and British holidaymakers it was found that the use of cocaine during the holiday was associated with involvement in fighting (with triple the odds) and use of cannabis with double the odds (Hughes, 2008).

Since drug addiction can destroy the country's future, via a negative change of human behavior on adolescents and young generation, therefore, the study was carried out to determine the extent of aggressive behaviors among adolescents who use drugs. This study was also conducted to determine the relationship between type of drug used with the actions and aggressive behaviors among them. The results of this study were expected not only to contribute to the improvement of prevention and rehabilitation programs of drug addicts, but the current findings can also be used to provide a wide range of policy reforms that can reduce the efffects of illicit drugs against violence and aggressive behaviors.

\section{Materials and Methods}

This research used cross-sectional survey and the data were analyzed using descriptive analysis and correlation. The aggressive behavior scale was developed by the researchers and was used to measure aggressive behavior among adolescents. The scale contains a total of 11 items (both positive and negative items combined). The respondents were asked to respond on a four scale of measurement: (1) Strongly Disagree, (2) Disagree, (3) Agree and (4) Strongly Agree.The Cronbach alpha coefficient of these studies showed a moderately high reliability for the set of questionnaires (0.74). Thus, the instrument used in this study indicated a good reliability. The level of aggressive behaviors among adolescents were measured based on the minimum score interpretation as shown in Table 1. (see Table 1).

Table 1. The mean score on the level of aggressive behaviors among adolescents involved in drug abuse activities

\begin{tabular}{ll}
\hline Mean score & Mean score interpretation \\
\hline$<2.00$ & Low level \\
$2.01-3.00$ & Moderate level \\
$3.01-4.00$ & High level \\
\hline
\end{tabular}

To determine whether there is a significant relationship between type of drug used by adolescents with aggressive behavior, Pearson correlation test based on the Guildford's (1973) Rule of Thumb was used as shown in Table 2. (see Table 2). 
Table 2. Pearson correlation - Guildford's (1973) rule of thumb

\begin{tabular}{ll}
\hline Pearson coefficient $(\mathbf{r})$ & The strength of relationship \\
\hline$<0.20$ & Almost no relationship \\
$0.20-0.40$ & Weak relationship \\
$0.41-0.70$ & Moderate relationship \\
$0.71-0.90$ & Strong relationship \\
$>0.90$ & Very strong relationship \\
\hline
\end{tabular}

Prior to the research, a research proposal together with a letter requesting for permission to conduct research at three Henry Gurney Schools were submitted to Director General of the Department of Malaysian Prison. The research instruments were only distributed after written consents were obtained from the Department of Malaysian Prison. A total number of 200 respondents were chosen using stratified random sampling as shown in Table 3. (see Table 3).

Table 3. Number of respondents by states

\begin{tabular}{llc}
\hline Institution & State & $(\mathbf{n}=\mathbf{2 0 0})$ \\
\hline Integriti School, Kajang & Selangor & 60 \\
Henry Gurney School, Keningau & Sabah & 50 \\
Henry Gurney School, Telok Mas & Melaka & 90
\end{tabular}

The questionnaires were then distributed to the adolescents aged between 13 to 21 years and were later collected by counselors from the respective Henry Gurney school. This procedure has achieved a high response rate $(100 \%)$ for this study. This is due to the high degree of cooperation between the respondents and the centers' counselors. The data were then analyzed using descriptive statistic through SPSS Version 15.

\section{Results and Discussion}

Aggressive behavior is a persistent pattern of behaviors that threaten or harm other people. Table 4 shows the level of aggressive behaviors among adolescents who were involved in drug abuse activities. This study found that the majority of adolescents showed the level of aggressive behaviors at a moderate level ( 74 percent). This situation gave the impression that those adolescents in the Department of Prison still showed the characteristics of aggressive behaviors. It can be concluded that the findings showed a higher level of aggressive behavior when they engaged in immoral activities. Therefore, effective approach is required in changing their behavior. Identification of the characteristics of aggressive behavior among the majority of adolescent iss reflected by the descriptive results of this study. (see Table 4)

Table 4. The level of aggressive behavior among adolescents involved in drug use activities

\begin{tabular}{ccc}
\hline Aggressive Behavior & $\mathbf{n = 2 0 0}$ & Percentage (\%) \\
\hline Low $(<2.00)$ & 10 & 5.0 \\
Moderate $(2.01-3.00)$ & 148 & 74.0 \\
High $(3.01-4.00)$ & 42 & 21.0 \\
\hline Total & $\mathbf{2 0 0}$ & $\mathbf{1 0 0}$
\end{tabular}

The results shown in Table 5 further indicated that 80 percent of the respondents admitted that they did not hesitate to use force only to defend themselves. Most of them (54.5 percent) agreed and strongly agreed, saying that some of their friends considered them as individuals who were easy to get angry. The results of the study showed that an adolescent who was getting rehabilitation should be given exposure with regards to an education about controling their negative emotions and aggressive behaviors. This is because the study found that 56 percent of the respondents had shown anger by way of subdivision and damage to the goods. Meanwhile, around 59 percent were still showing the characteristics of aggressive behavior, where they did not think twice to beat someone if the person challenge them.

Although there are adolescents who had shown aggressive behaviors in this study, but they also showed the characteristics of balanced behavior in terms of their good behavior. The study also found that 58.5 percent of respondents strongly disagreed and disagreed with the statement that they were easy and quick to turn their anger on others. While 61 percent of 200 adolescents of the research admitted that they were able to control themselves from fighting, especially when others did not agree with the views expressed by them. (see Table 5). 
Table 5. Distribution percentage of adolescent aggressive behavior

\begin{tabular}{|c|c|c|c|c|c|c|}
\hline \multirow[t]{2}{*}{ No } & \multirow[t]{2}{*}{ Item } & 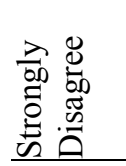 & 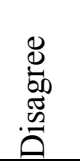 & 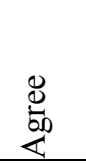 & 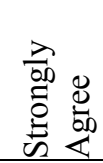 & Mean \\
\hline & & $\mathrm{f}(\%)$ & $f(\%)$ & $\mathrm{f}(\%)$ & $f(\%)$ & $f(\%)$ \\
\hline \multirow[t]{2}{*}{1} & \multirow{2}{*}{$\begin{array}{l}\text { If necessary use force to protect my rights, } \\
\text { I will use it. }\end{array}$} & 4.0 & 16.0 & 57.5 & 22.5 & 2.98 \\
\hline & & \multicolumn{2}{|c|}{20.0} & \multicolumn{2}{|c|}{80.0} & \\
\hline \multirow[t]{2}{*}{2} & \multirow{2}{*}{$\begin{array}{l}\text { Some of my friends think that I am an } \\
\text { easily feel angry }\end{array}$} & 9.0 & 36.5 & 42.0 & 12.5 & 2.58 \\
\hline & & \multicolumn{2}{|c|}{45.5} & \multicolumn{2}{|c|}{54.5} & \\
\hline \multirow[t]{2}{*}{3} & \multirow{2}{*}{$\begin{array}{l}\text { I used to show my anger by breaking and } \\
\text { damaging goods }\end{array}$} & 10.0 & 34.0 & 36.5 & 19.5 & 2.66 \\
\hline & & \multicolumn{2}{|c|}{44.0} & \multicolumn{2}{|c|}{56.0} & \\
\hline \multirow[t]{2}{*}{4} & \multirow{2}{*}{$\begin{array}{l}\text { I probably beat someone if he challenged } \\
\text { me }\end{array}$} & 8.5 & 32.5 & 44.0 & 15.0 & 2.66 \\
\hline & & \multicolumn{2}{|c|}{41.0} & \multicolumn{2}{|c|}{59.0} & \\
\hline \multirow[t]{2}{*}{5} & \multirow{2}{*}{$\begin{array}{l}\text { I always get angry fast and quick venting } \\
\text { to others }\end{array}$} & 14.5 & 44.0 & 32.5 & 9.0 & 2.36 \\
\hline & & \multicolumn{2}{|c|}{58.5} & \multicolumn{2}{|c|}{41.5} & \\
\hline \multirow[t]{2}{*}{6} & \multirow{2}{*}{$\begin{array}{l}\text { I could not refrain from fighting when } \\
\text { others do not agree with me }\end{array}$} & 12.5 & 48.5 & 31.5 & 7.5 & 2.34 \\
\hline & & \multicolumn{2}{|c|}{61.0} & \multicolumn{2}{|c|}{39.0} & \\
\hline
\end{tabular}

Results in Table 6 shows the relationship between types of drug abuse and aggressive behavior among adolescents. The study found that adolescents who used heroin $(\mathrm{r}=0.016, \mathrm{p}<0.05)$ and morphine drug $(\mathrm{r}=0.181$, $\mathrm{p}<0.05$ ) showed significant relationship with aggressive behavior. Therefore, the use of heroin and morphine drug among adolescents can increase aggressive behavior compared to the other drugs. These findings are consistent with literature findings that heroin users were those who showed signs and characteristics such as insomnia, easily agitated, often felt anxious and upset (Jamaludin 2007; Diane \& Samatha, 2009). The use of heroin and morphine was also the most dangerous of drugs with a higher potential to cause an addiction (Abdul Ghafar, 2005). Hence, the use of drugs should be taken into consideration in handling the drug rehabilitation process to ensure that they can be successfully treated to be free of the drug influence. (see Table 6).

Table 6. The relationship between types of drug used with aggressive behavior

\begin{tabular}{|c|c|}
\hline Type of Drug & $\begin{array}{l}\text { Aggressive Behavior } \\
\qquad(\mathrm{n}=\mathbf{2 0 0})\end{array}$ \\
\hline Heroin & $0.168^{*}$ \\
\hline Morphine & $0.181^{*}$ \\
\hline Opium & 0.084 \\
\hline Methamphetamine & 0.049 \\
\hline Amphetamines & 0.079 \\
\hline Cannabis & 0.056 \\
\hline Other Drugs & 0.005 \\
\hline
\end{tabular}

$$
{ }^{*} \mathrm{p}<0 . \overline{05}
$$

\section{Conclusion}

It can be concluded from the results of the present study that many adolescents who are currently seeking rehabilitation should be empowered towards addressing their aggressive behavior. This situation must be addressed promptly to prevent adolescents from being aggressive. The study also found that adolescents using heroin and morphine showed significant relationship with aggressive behaviors. Therefore, the findings have implications towards policy implementation to enhance the rehabilitation modules on adolescents involved in 
drug use. Education on how to effectively deal with aggressive behavior among adolescents at risk should be emphasized by the party responsible for building positive behavior among adolescents in order to produce an outstanding young generation. Adolescents who are seeking recovery need to know some skills or techniques to change their aggressive behaviors and avoid negative actions. The focus of rehabilitation of those adolescents at risk should also be highlighted to the respondents who took heroin and morphine as an effort to control their aggressive behavior at the early stage of effective drug treatment.

\section{Acknowledgements}

The researchers have been supported generously by Prisons Department of Malaysia and the Faculty of Social Sciences and Humanities, Universiti Kebangsaan Malaysia on UKM-GGPM-CMNB-007-2010 grant. The researchers would like to express their sincere appreciation for all the support provided.

\section{References}

Abd. Rahim Abd Rashid, Sufean Hussin, \& Jamaludin Tubah. (2006). Family Institutions Face The New Millennium. Kuala Lumpur: Utusan Publications Distributions Sdn Bhd, p.77

Abdul Ghafar Taib. (2005). Joint War Against Drugs. Kuala Lumpur: Sri Kenanga Sdn Bhd Publisher.

Arnett, J. (1999). Adolescent storm and stress, reconsidered. American Psychologist, 54(5), 317-326. http://dx.doi.org/10.1037/0003-066X.54.5.317

Baron, R. A., \& Richardson, D. (1994). Human aggression. New York: Plenum Press.

Ben-Porath D., \& Taylor S. P. (2002). The effects of diazepam (valium) and aggressive disposition on human aggression: An experimental investigation. Addictive Behaviors, 27(2), 167-177. http://dx.doi.org/10.1111/j.1360-0443.1997.tb03203.

Berman, M., Gladue, B., \& Taylor, S. (1993). The effects of hormones, Type A behavior pattern, and provocation on aggression in men. Motivation and Emotion, 17(2), 125-138. http://dx.doi.org/10.1007/BF00995189.

Boles M., \& Miotto K. (2003). Substance use and violence: A review of the literature. Aggression and Violent Behavior, 8(1), 55-174. http://dx.doi.org/10.1016/S1359-1789(01)00057-X

Chermack S., \& Blow, F. (2002). Violence among individuals in substance abuse treatment: The role of alcohol and cocaine consumption. Drug and Alcohol Dependence, 66(1), 29-37. http://dx.doi.org/10.1016/S0376-8716(01)00180-6,

Coie, J. D., \& Dodge, K. A. (2000). Aggression and antisocial behavior. In W. Damon (Series Ed.) \& N. Eisenberg (Vol. Ed.), Handbook of child psychology: Vol. 3. Social, emotional, and personality development ( $5^{\text {th }}$ ed., pp. 779-862). New York: Wiley.

Davis, W. M. (1996). Psychopharmacologic violence associated with cocaine abuse: Kindling of a limbicdyscontrol syndrome? Progress in Neuro-Psychopharmacology and Biological Psychiatry, 20(8), 1273-1300. http://dx.doi.org/10.1016/S0278-5846(96)00126

Diane, S. A., \& Samatha, J. V. (2009). Drug theraphy in nursing (3rd ed.). China: Wolters Kluwer Health.

Drug Report. (2011). National Anti-Drug Agency of Malaysia. Putrajaya: Kuala Lumpur

Fauziah Ibrahim, Mustaffa Omar, Lukman Zawawi Mohamad, Khadijah Alavi, Norulhuda Sarnon, Salinan Nen, \& Nasrudin Subhi. (2011a). Employment barriers against people with drug use histories. Pertanika Journal of Social Sciences \& Humanities, 19(S), 109-114.

Fauziah Ibrahim, Naresh Kumar, \& Bahaman Abu Samah. (2011b). Self efficacy and relapsed addiction tendency: An empirical study. The Social Sciences, 6(4), 277-282. http://dx.doi.org/10.3923/sscience.2011.277.282

Geen, R. G. (1990). Human aggression. Pacific Grove, CA: Brooks/Cole.

Geen, R. G. (1998a). Aggression and antisocial behavior. In D. T. Gilbert, S. T. Fiske, \& G. Lindzey (Eds.), The handbook of social psychology (4th ed., Vol. 2, pp. 317-356). New York: McGraw-Hill.

Geen, R. G. (1998b). Processes and personal variables in affective aggression. In R. G. Geen \& E. Donnerstein (Eds.), Human aggression: Theories, research, and implications for policy (pp. 1-21). New York: Academic Press.

Guildford, J. P. (1973). Fundamental statistics in psychology and education ( $5^{\text {th }}$ ed.) New York: McGraw-Hill. 
Hughes, K., Bellis, M. A., Calafat, A., Juan, M., Schnitzer, S., \& Anderson, Z. (2008). Predictors of violence in young tourists: A comparative study of British, German and Spanish holidaymakers. European Journal of Public Health, 18(6), 569-574. http://dx.doi.org/10.1002/14651858

Jamaludin Haji Ahmad. (2007). Modul \& kaunseling penyalahgunaan dadah. Serdang: Penerbit Universiti Putra Malaysia.

Kuhns, J. B. (2005). The dynamic nature of the drug use/serious violence relationship: A multi-causal approach. Violence and Victims, 20(4), 433-454. http://dx.doi.org/10.1891/0886-6708.20.4.433

MacDonald, S., Erickson, P., Wells, S., Hathaway, A., \& Pakula, B . (2008). Predicting violence among cocaine, cannabis and alcohol treatment clients. Addictive Behaviors, 33(1), 201-205. http://dx.doi.org/10.1016/j.addbeh.2007.07.002

Moore, T. M., \& Stuart, G. L. (2003). A review of the literature on marijuana and interpersonal violence. Aggression and Violent Behavior, 10(2), 171-192. http://dx.doi.org/10.1016/j.avb.2003.10.002

Reid, L. W., Elifson, K. W., \& Sterk, C. E. (2007). Hug drug or thug drug? Ecstasy use and aggressive behavior. Violence and Victims, 22(1), 104-119. http://dx.doi.org/10.1891/088667007780482892

Sickmund, M., Snyder, H. N., \& Poe-Yamagata, E. (1997). Juvenile offenders and victims: 1997 update on violence. Washington, DC: Office of Juvenile Justice and Delinquency Prevention.

Taylor, S. P., \& Hulsizer, M. R. (1998). Psychoactive drugs and human aggression. Academic Press.

Xu X., Fengchuan, R. N., Patricia, M. A., Victoria, M., \& Jacquelyn, C. (2005). Prevalence of and risk factors for intimate partner violence in China. American Journal of Public Health, 95(1), 78-85. http://dx.doi.org/10.2105/AJPH.2003.023978 